\title{
STOSUNKI AMERYKAŃSKO-IRAŃSKIE JAKO PRZYKŁAD PRÓBY ZBLIŻENIA WROGICH PAŃSTW Z WYKORZYSTANIEM SPORTU*
}

\author{
AMERICAN-IRANIAN RELATIONS AS AN EXAMPLE \\ OF AN ATTEMPT OF POLITICAL RAPPROCHEMENT \\ WITH THE USE OF SPORT
}

Michał Marcin Kobierecki**

\begin{abstract}
ABSTRAKT
Celem artykułu jest zbadanie dyplomacji sportowej pomiędzy Iranem a Stanami Zjednoczonymi, która stanowi przykład dyplomacji sportowej ukierunkowanej na zbliżenie nieprzychylnych względem siebie państw. Kraje te nie utrzymują bowiem stosunków dyplomatycznych, a ich wzajemne relacje można scharakteryzować jako wrogie. Pod koniec XX wieku dwa państwa zaczęły nawiązywać kontakty sportowe ukierunkowane na wspieranie zbliżenia.

W artykule podjęta została próba weryfikacji hipotezy, zgodnie z którą dyplomacja sportowa pomiędzy USA i Iranem miała znaczenie jedynie wtórne i nie byłaby możliwa bez woli politycznej. Podjęta zostanie ponadto próba analizy doboru poszczególnych dyscyplin sportowych wykorzystanych w ramach dyplomacji sportowej pomię-
\end{abstract}

The aim of the article is to investigate sports diplomacy between Iran and the United States, which is an example of sports diplomacy directed at bringing unfriendly states closer. The two countries do not have diplomatic relations and their mutual attitude can be described as hostile. At the end of the $20^{\text {th }}$ century they started to establish sports exchanges aimed at supporting political rapprochement.

The article is aimed to verify a hypothesis stating that the significance of sports diplomacy between Iran and the United States was secondary and it would not be possible without the political will of both sides. Also, an attempt to analyze the selection of sports disciplines used for sports diplomacy between the two states

* Badanie przeprowadzone dzięki finansowaniu Narodowego Centrum Nauki w ramach projektu badawczego nr 2015/19/D/HS5/00513.

** Uniwersytet Łódzki, Wydział Studiów Międzynarodowych i Politologicznych. 
dzy Iranem a USA, jeśli chodzi o ich pozytywny bądź negatywny wpływ na jej skuteczność.

Słowa kluczowe: dyplomacja sportowa, stosunki USA-Iran, sport i polityka concerning their positive or negative effect on its efficiency has been made.

Keywords: sports diplomacy, USA-Iran relations, sport and politics

\section{WPROWADZENIE}

Dyplomacja sportowa stanowi kategorię naukową, która obecnie dopiero uobecnia się w obiegu naukowym, szczególnie w Polsce. Z jej istotności jako części dyplomacji publicznej wydają się jednak zdawać sobie sprawę władze Polski, przykładowo zagadnieniu dyplomacji sportowej było poświęcone współorganizowane przez Ministerstwo Sportu i Turystyki oraz Ministerstwo Spraw Zagranicznych RP w październiku 2014 roku sympozjum naukowe (Polski Komitet Olimpijski, 2014), a także wspomniano o niej w raporcie MSZ poświęconym dyplomacji publicznej (Ministerstwo Spraw Zagranicznych RP, 2014). Wydaje się jednak, iż dyplomacja sportowa w dalszym ciągu pozostaje niewystarczająco doceniania jako narzędzie prowadzenia polityki międzynarodowej. Jest to bowiem pojęcie znacznie szersze niż tylko element budowania wizerunku i prestiżu międzynarodowego państwa. Tymczasem w nauce światowej dyplomacja sportowa wydaje się pod tym względem bardziej doceniana i poświęcane są jej kolejne analizy. Istnieje $\mathrm{w}$ związku $\mathrm{z}$ tym potrzeba, aby badać zagadnienie dyplomacji sportowej i eksploatować jej potencjał jako narzędzia prowadzenia polityki międzynarodowej.

Dyplomacja sportowa jest pojęciem stosunkowo szerokim i rozumianym na wiele sposobów. Może obejmować wykorzystywanie sportu jako narzędzia zbliżenia między państwami bądź przeniesienia na grunt sportowy politycznych konfliktów, a także służyć kształtowaniu wizerunku międzynarodowego traktując sport jako jeden z elementów miękkiej siły państwa. Podmiotami dyplomacji sportowej mogą być zarówno państwa, jak i aktorzy niepaństwowi, np. organizacje zarządzające sportem, organizacje pozarządowe, sportowcy itp. Jest to więc pojęcie o niezwykle szerokim zakresie. Niniejszy artykuł dotyczy dyplomacji sportowej będącej narzędziem wspierania celów polityki zagranicznej państw, a zarazem tworzenia okoliczności dla zbliżenia politycznego pomiędzy państwami nieprzychylnymi względem siebie. 
Badania podjęte w niniejszym artykule mają charakter studium przypadku poświęconego dyplomacji sportowej pomiędzy dwoma państwami, które z całą pewnością można uznać za nieprzychylne względem siebie, mianowicie Stanami Zjednoczonymi i Iranem. Casus ten posłuży do skonstruowania uogólnień dotyczących dyplomacji sportowej jako narzędzia promowania zbliżenia pomiędzy wrogimi sobie państwami. Badanie będzie więc miało charakter empiryczny $\mathrm{i}$ oparte będzie na rozumowaniu indukcyjnym. Casus ten jest o tyle istotny, iż w ostatnim czasie doszło do pewnego przełomu dotyczącego stosunków pomiędzy dwoma krajami, którego symbolem jest porozumienie nuklearne z lipca 2015 roku.

Celem badania jest dokonanie kompleksowej analizy przejawów dyplomacji sportowej, do jakich doszło na linii Stany Zjednoczone-Iran na przełomie XX i XXI wieku. Podjęta zostanie próba weryfikacji hipotezy dotyczącej roli dyplomacji sportowej w kształtowaniu stosunków pomiędzy dwoma skonfliktowanymi państwami, jakimi były Stany Zjednoczone i Iran, zgodnie z którą dyplomacja sportowa sama nie jest $\mathrm{w}$ stanie doprowadzić do politycznego przełomu - bez politycznej woli ku temu, jej znaczenie pozostaje zatem jedynie wtórne. Podjęta zostanie ponadto próba analizy doboru poszczególnych dyscyplin sportowych wykorzystanych w ramach dyplomacji sportowej pomiędzy Iranem a USA, jeśli chodzi o ich pozytywny bądź negatywny wpływ na jej skuteczność.

\section{GENEZA DYPLOMACJI SPORTOWEJ IRAN-USA}

W kontekście analizy dyplomacji sportowej pomiędzy Stanami Zjednoczonymi a Iranem niezwykle istotny jest kontekst historyczny związany z relacjami pomiędzy tymi krajami. Państwa te należały do bliskich sojuszników za czasów rządów w Iranie proamerykańskiego szacha Mohammeda Rezy Pahlawiego. Sytuacja uległa zmianie po obaleniu szacha w styczniu 1979 roku, natomiast do zerwania stosunków dyplomatycznych doszło w efekcie zajęcia ambasady Stanów Zjednoczonych w Teheranie przez radykalnych studentów islamskich i wzięcia przez nich zakładników. W efekcie 7 kwietnia 1980 roku USA zerwały stosunki dyplomatyczne $\mathrm{z}$ Iranem, kraje zaś silnie zantagonizowały się, a ich relacje stały się bardzo napięte. Stany Zjednoczone i Iran do chwili obecnej nie utrzymują formalnych stosunków dyplomatycznych.

Stosunki amerykańsko-irańskie po rewolucji islamskiej należałoby określić jako nieprzychylne i pełne braku zaufania (Kaussler, Newkirk, 2012). Sytuacja 
zaczęła ulegać powolnej zmianie dopiero w drugiej połowie lat 90. Ze względów geostrategicznych prezydent USA Bill Clinton podjął bowiem starania, aby odnowić stosunki z Iranem. Do zmiany władzy doszło także w Teheranie, ponieważ w 1997 roku prezydentem wybrano bardziej postępowego polityka Mohammeda Chatamiego, co także wpłynęło na zwiększenie szans na zmianę w stosunkach dwustronnych (Amado, Amato, 2001). Właśnie wspomniana zmiana przywódców obu państw na bardziej skłonnych do porozumienia w głównej mierze przyczyniła się późniejszego zastosowania dyplomacji sportowej. Widać tu analogię także do innych przejawów dyplomacji sportowej, ukierunkowanej na zbliżenie między narodami pozostającymi w konflikcie, jak chociażby Armenią i Turcją, pomiędzy którymi doszło do tzw. dyplomacji futbolowej w następstwie objęcia władzy przez prezydentów Serzha Sarkisyana i Abdullah Güla.

Stopniowe wzajemne otwieranie się Iranu i USA oparte było przede wszystkim na kontaktach oddolnych, tzw. międzyludzkich, na co nalegać miała przede wszystkim strona irańska. I tak prezydent Chatami po objęciu rządów stwierdzić miał w wywiadzie udzielonym Christianne Amanpour z CNN, że wymiana kulturalna pomiędzy USA a Iranem mogłaby pomóc w „zburzeniu ściany nieufności”. Strona amerykańska zdawała się zaakceptować propozycję i już wkrótce rozpoczęto wymianę kulturalną, w dużej mierze opartą na wymianie sportowej (Milinski, 2010). Co prawda Amerykanie początkowo rozważali otwarcie za pośrednictwem tradycyjnych kontaktów dyplomatycznych - już we wskazanym 1997 roku administracja Clintona zintensyfikowała wysiłki w tym celu. W październiku tego roku za pośrednictwem ambasady Szwajcarii w Teheranie wystosowano bowiem propozycję spotkania bez warunków wstępnych, które miałoby się odbyć we wskazanym miejscu w Iranie. W spotkaniu mieliby wziąć udział trzej wysoko postawieni przedstawiciele Stanów Zjednoczonych, jednak Iran nie odpowiedział pozytywnie na tę propozycję. Z kolei w maju 1998 roku podczas wizyty w Arabii Saudyjskiej wiceprezydent USA Al Gore poprosił księcia Abdullaha o zorganizowanie bezpośrednich rozmów pomiędzy Teheranem a Waszyngtonem. Iran znów jednak odmówił, zaznaczając, iż przed otwarciem kontaktów międzyrządowych należy rozwijać kontakty typu people-to-people. Co prawda, kontakty międzyrządowe odbywały się, ale jedynie w środowisku multilateralnym, np. w Organizacji Narodów Zjednoczonych (Kriesberg, 2015). Chatami był bowiem zwolennikiem kontaktów międzyludzkich jako narzędzia przełamania lodów (Chehabi, 2001), nawołując zarazem do „dialogu cywilizacji” (Hauss, 2015, s. 383). Efektem takiej deklaracji były m.in. wymiany sportowe, 
do których miało wkrótce dojść. Chociaż biorąc pod uwagę odrzuconą przez Iran możliwość politycznego otwarcia, można to uznać za jedynie częściowy progres, to trzeba pamiętać, iż we wcześniejszym okresie dwa państwa właściwie nie utrzymywały kontaktów. Biorąc to pod uwagę, nawiązanie nawet oddolnych wymian, w tym sportowych, należałoby jednak ocenić jako pewien przełom.

\section{AMERYKAŃSKO-IRAŃSKIE WYMIANY ZAPAŚNICZE}

W kontekście dyplomacji sportowej pomiędzy Stanami Zjednoczonymi a Iranem najczęściej analizowany jest mecz piłkarski, do którego doszło latem 1998 roku podczas odbywających się we Francji Mistrzostw Świata w piłce nożnej. Jednak jeszcze zanim do niego doszło, miał miejsce inny akord dyplomacji sportowej pomiędzy dwoma krajami, bowiem doszło do wizyty amerykańskiej drużyny zapaśniczej w Iranie, gdzie wzięła udział w turnieju Takhti. Doszło do tego przy znaczącym udziale amerykańskiej organizacji pozarządowej Search for Common Ground, której celem było poszukiwanie kooperacyjnych sposobów rozwiązania impasu w stosunkach dwustronnych. Wizyta była jednocześnie pierwszą sytuacją od czasu zerwania stosunków dyplomatycznych, kiedy to na terytorium Iranu wywieszono amerykańską flagę (Hauss, 2015; Kessler, 2009). Wspomniana organizacja odbyła wiele negocjacji z szeregiem instytucji w USA i Iranie dotyczących kwestii bezpieczeństwa, politycznych itp. Na skutek ich sukcesu udało się wysłać do Iranu drużynę pięciu zapaśników, którzy wzięli udział w turnieju jako jedna z 17 drużyn. Warto dodać, iż turniej ten był bardzo popularny w Iranie - był transmitowany przez narodową telewizję i budził duże zainteresowanie (Asgharirad, 2012). Fakt przyczynienia się do zorganizowania wyjazdu przez organizację pozarządową wydaje się w tym kontekście bardzo istotny, bowiem ewentualne fiasko inicjatywy nie wpływałoby niekorzystnie na prestiż w tym przypadku rządu Stanów Zjednoczonych. Dodawało to ponadto inicjatywie oddolnego charakteru, mimo że nie ulega wątpliwości, iż na kontakt sportowy musiały wydać zgodę polityczne władze obu krajów.

Do zaproszenia amerykańskiej drużyny zapaśniczej doszło w lutym 1998 roku. Co ciekawe, nie była to pierwsza tego typu inicjatywa, jednak wcześniej ze względów bezpieczeństwa Amerykanie odmawiali wzięcia udziału w tych cyklicznych zawodach. Podczas turnieju Amerykanie byli bardzo dobrze odbierani przez publiczność - 12000 kibiców w hali Azadi Sports Hall miało ich entuzjastycznie dopingować. 
Generalnie trudno było dostrzec antypatie dwóch stron. Pojawiały się przy tym wzajemne gesty dobrej woli i sympatii, przykładowo jeden $\mathrm{z}$ amerykańskich zawodników, Zeke Jones, miał machać miniaturową flagą Iranu, w odpowiedzi na co widzowie zaczęli skandować „America”. Symboliczny był też serdeczny, przedłużony uścisk po walce Melvina Douglasa i Abbasa Jedidiego (Kessler, 2009). Co więcej, na trybunach pojawiły się też okrzyki popierające prezydenta Chatamiego, gdy w hali pojawił się konserwatywny polityk Ali-Akbar Nategh Nuri. Wskazywało to na głęboką przemianę tradycyjnie antyamerykańskiej opinii publicznej w Iranie. Wydawali się dostrzec to Amerykanie, bowiem kiedy drużynę zapaśników 13 marca 1998 roku przyjął prezydent Clinton, zachęcał także innych Amerykanów do uczestniczenia w wymianach z Iranem (Chehabi, 2001). Wspomnieć w tym miejscu warto, że zapasy należały do dyscyplin sportowych, w których wymiany amerykańsko-irańskie były szczególnie liczne, czego jednym z głównych powodów było zbliżenie się federacji zapaśniczych obu państw podczas Mistrzostw Świata w 1995 roku (Khanlari, 2014). Warto w tym miejscu zwrócić uwagę na potencjał dyplomacji sportowej, uznawanej za część dyplomacji publicznej, we wpływaniu na postawę społeczeństw. Poprzez często spontaniczne, pozytywne gesty zwykłych ludzi - sportowców czy kibiców - pomiędzy społeczeństwami może wywiązać się pewien rodzaj więzi, który może być trudny do osiągnięcia poprzez tradycyjne działania dyplomatyczne.

W opisanym wydarzeniu można zidentyfikować pewien mechanizm odnoszący się do wykorzystywania dyplomacji sportowej, a także szerzej dyplomacji publicznej, w staraniach zantagonizowanych państw odnośnie do poprawy stanu stosunków wzajemnych. Z uwagi na szereg uwarunkowań nie było wówczas możliwe nawiązanie otwartego dialogu. W związku z tym, jako swoisty gest inicjujący zbliżenie, może być wykorzystane wystosowanie przez federację sportową zaproszenia do udziału w towarzyskiej rywalizacji sportowej. W tym przypadku widoczne było ponadto pozytywne nastawienie irańskich kibiców względem amerykańskich gości. To z kolei mogło być odczytane przez władze obydwu państw za oznakę gotowości Irańczyków do otwarcia na Stany Zjednoczone. Było to o tyle ważne, iż niekiedy w historii kontakty sportowe nie szły w parze z przemianami w społecznym postrzeganiu pewnych kwestii. Tym razem, jak się zdaje, oddolna gotowość na zbliżenie dwóch państw miała miejsce.

Zdaniem Davida Kesslera (2009) ów zapaśniczy epizod dyplomacji sportowej okazał się korzystny dla obu stron. Dla Amerykanów stanowił on możliwość ponownego zaprezentowania się ludowi Iranu, podczas gdy dla Irańczyków szansę na zerwanie $\mathrm{z}$ „nieprzejednanymi ajatollahami uosabiającymi ich kraj” 
(s. 41). Chociaż w tej wypowiedzi można dostrzec pewną przesadę, to zgodzić się trzeba z poglądem o przełomowości kontaktu - wobec niemal całkowitego braku takowych we wcześniejszych latach. Jednocześnie jednak trudno wyobrazić sobie możliwość takiej wymiany typu people-to-people, gdyby nie objęcie władzy w obu krajach przez bardziej skorych do dialogu przywódców. Mówiąc o przełomowości zainicjowania swoistej dyplomacji zapaśniczej, nie można zatem pominąć przede wszystkim znaczenia wcześniejszych gestów prezydenta Iranu.

Opisany kontakt w zapasach nie był jednorazowym przejawem dyplomacji sportowej, ale początkiem całej serii licznych kontaktów zapaśniczych, a z czasem także kontaktów w innych sportach. Zatem niedługo po turnieju Takhti, bo już w kwietniu 1998 roku, doszło do wizyty reprezentacji Iranu w zapasach w USA - przy okazji odbywającego się tam Pucharu Świata. Amerykanie nie odwzajemnili jednak gościnności Irańczyków, bowiem zapaśnicy z tego kraju musieli spędzić na lotnisku w Chicago dwie godziny podczas kontroli bezpieczeństwa. Wspomniana kontrola, mimo że Amerykanie twierdzili, iż są to standardowe procedury, została bardzo negatywnie odebrana w Iranie. Twierdzi się wręcz, iż mogło to ponownie pobudzić w tamtejszym społeczeństwie sentyment, zgodnie z którym „Amerykanom nie można ufać”. Incydent został także potępiony przez irańskie ministerstwo spraw zagranicznych. Aby załagodzić powstałe napięcie, Biały Dom zaprosił 18-osobową drużynę irańską na specjalne zwiedzanie Muzeum Powietrza i Przestrzeni Instytutu Smithsoniańskiego, prowadzone przez biegłą w języku perskim amerykańską Sekretarz Zdrowia i Opieki Społecznej Donnę Shalala’ę. Rozgoryczeni Irańczycy odrzucili jednak propozycję (Asgharirad, 2012; Kessler, 2009). Mimo urazy udało się natomiast przekonać irańskich zapaśników do wzięcia udziału w odbywających się w Nowym Jorku w lipcu 1998 roku Igrzyskach Dobrej Woli (Goodwill Games). Tym razem, jeszcze przed wizytą, poczyniono ustalenia, iż zawodnikom nie będą pobierane odciski palców na granicy, jednak także i podczas tej wizyty doszło do kontrowersji, bowiem w trakcie zawodów grupa emigrantów irańskich wykrzykiwała hasła skierowane przeciwko rządowi irańskiemu. Pomijając jednak ten incydent, drużyna Iranu pozytywnie odebrała wizytę, mówiono także „otwarciu dialogu” (Asgharirad, 2012, s. 93).

Jak widać, pomimo znaczącego incydentu związanego z pobieraniem odcisków palców od delegacji irańskiej przez amerykańskie służby graniczne, udało się kontynuować „dyplomację zapaśniczą”. Oczywiście trudno dziwić się takiemu odbiorowi sytuacji przez stronę irańską. Pobieranie odcisków palców w sposób uniwersalny przywodzi na myśl traktowanie przestępców. Tymczasem stosunki 
Iranu i Stanów Zjednoczonych, pomimo pewnego ocieplenia, wciąż były bardzo „delikatne” i „wrażliwe”. Wydaje się jednak, iż incydent nie zaprzepaścił w pełni wcześniejszych starań obu stron.

\section{MECZ PODCZAS MISTRZOSTW ŚWIATA W PIŁCE NOŻNEJ W 1998 ROKU}

Na szczególną uwagę w kontekście roli sportu w rozwoju relacji amerykańsko-irańskich zasługuje mecz piłkarski pomiędzy tymi krajami. Do spotkania takiego doszło podczas Mistrzostw Świata w piłce nożnej, odbywających się we Francji w 1998 roku. Nie była to zatem inicjatywa żadnego z państw, ale efekt losowania grup mistrzostw. Znacznie ma w tym przypadku również fakt, iż do spotkania sportowego doszło na terenie „neutralnym” - we Francji, nie zaś na terytorium któregoś z zainteresowanych państw. Istotna była także waga spotkania, bowiem Mistrzostwa Świata w piłce nożnej są najważniejszym wydarzeniem w tej dyscyplinie sportu i w pewnym sensie symbolem globalizacji (Miller, Lawrence, McKay, Rowe, 2001). Dla Iranu istotne było już samo zakwalifikowanie się do turnieju, co zostało w tym kraju przyjęte niemal z histeryczną radością (Amado, Amato, 2001), nawet bardziej entuzjastycznie niż pierwsze miejsce Iranu w Mistrzostwach Świata w zapasach w 1998 roku, które są przecież uznawane za sport narodowy w tym kraju (Chehabi, 2006). Manifestacje radości przekształcały się zarazem w demonstracje poparcia dla Chatamiego (Chehabi, 2001), co dodawało całemu wydarzeniu politycznego kolorytu.

Na skutek losowania grup Mistrzostw Świata, do którego doszło w grudniu 1997 roku, oba zespoły trafily do grupy F. Na skutek tego w Iranie pojawily się nastroje związane $\mathrm{z}$ chęcią wspierania bardziej normalnych relacji z resztą świata (Amado, Amato, 2001), w szczególności ze Stanami Zjednoczonymi. W związku z tym już pod koniec 1997 roku, a zatem zanim jeszcze doszło do wymian zapaśniczych, wiadomo było, iż będzie miał miejsce kontakt sportowy pomiędzy dwoma krajami. Niewiadomą pozostawało jedynie, czy zostanie on wykorzystany w celach politycznych, a jeśli tak, to czy jako element walki ideologicznej, czy też jako okazja do zbliżenia poprzez dyplomację sportową.

Po zakwalifikowaniu się do turnieju finałowego Mistrzostw Świata w piłce nożnej wśród działaczy sportowych w Iranie doszło do sporów w kwestii podejścia do udziału w imprezie. Zwycięzcy okazali się zwolennicy prezydenta Chatamiego. Ustalono zatem, że udział w mistrzostwach będzie okazją do zmiany 
międzynarodowego wizerunku tego kraju. W związku z tym zawodnicy irańscy otrzymali instrukcje, aby przystępowali do meczów w sposób schludny, mieli być dokładnie ogoleni oraz mieli wręczać przeciwnikom przed meczami bukiety kwiatów (Chehabi, 2001). W zachowaniu tym można dostrzec ważną funkcję dyplomacji sportowej, to jest przezwyciężanie stereotypów - poprzez schludny wygląd i grzeczne zachowanie irańscy piłkarze mieli uderzać w stereotyp Irańczyka jako „złośliwego i anty-zachodniego wojownika” (Kessler, 2009, s. 40). Przypadek ten można zatem analizować także jako sposób budowania wizerunku międzynarodowego państwa i narodu.

W związku z mającym się odbyć meczem USA-Iran służby dyplomatyczne obu krajów podjęły próby wykorzystania go w celu poprawy relacji. Takie nastawienie obu państw można było dostrzec np. w wypowiedziach polityków amerykańskich. Sekretarz stanu Madeleine Albright mówiła o chęci stworzenia „mapy drogowej prowadzącej do normalnych stosunków”, a także wspominała o dużym szacunku dla nauk moralnych islamu (Amado, Amato, 2001, s. 107) oraz o nadziei na „normalne stosunki” pomiędzy państwami. Z kolei prezydent Stanów Zjednoczonych Bill Clinton powiedział, że Iran zmienia się na lepsze oraz że Stany Zjednoczone chcą to wspierać. Kilka godzin przed samym meczem M. Albright powiedziała także, iż zrozumiałe jest, że Irańczycy czują rozgoryczenie względem Stanów Zjednoczonych (Marlowe, 1998). W innej wypowiedzi prezydent Clinton zasugerował także, iż ma nadzieję, że mający się odbyć mecz piłkarski będzie „krokiem naprzód w celu zakończenia napięcia pomiędzy narodami”, po meczu zaś prezydent pogratulował zespołowi Iranu (Chehabi, 2001, s. 99). Clinton powiedział także: „razem z prezydentem Chatami’m pracowałem, aby zachęcić do wzmożenia wymian typu people-to-people, co może pomóc naszym obywatelom rozwinąć lepsze zrozumienie dla naszych bogatych cywilizacji”" (Kessler, 2009, s. 42). Amerykański prezydent wspomniał przy tym, iż wiele dla niego znaczyło to, że odwiedzający Iran amerykańscy zapaśnicy byli traktowani z szacunkiem i przyjaźnią (Public Papers of the Presidents..., 1998). Jak widać, strona amerykańska wielokrotnie podkreślała, iż jej intencją jest otwarcie na Iran, mecz piłkarski był zaś dobrą do tego okolicznością.

Chociaż politycy irańscy nie wypowiadali się tak jednoznacznie, to ze strony tego kraju także można było dostrzec szereg gestów świadczących o chęci dyplomatycznego wykorzystania spotkania. I tak przed meczem strona irańska przygotowała dla każdego piłkarza obecnego na boisku podczas rozpoczęcia spotkania białą różę - symbol pokoju w Iranie (Billingham, 2014). Kwiaty, a także srebrna taca herbaciana zostały podarowane piłkarzom amerykańskim, ci 
z kolei wręczyli Irańczykom tradycyjne proporczyki. Ponadto uściski dłoni były wyjątkowo długotrwałe (Marlowe, 1998; Amado, Amato, 2001). Przed meczem zawodnicy obu drużyn mieli być poinstruowani, aby grać w sposób kulturalny (Chehabi, 2001). Za pokojowy symbol spotkania uznano także fakt, iż obie drużyny, zamiast oddzielnie, pozowały do pamiątkowego zdjęcia wspólnie, obejmując się wzajemnie (Marlowe, 1998). Po meczu nastąpiła tradycyjna wymiana koszulek. Warto wspomnieć, iż dwa zespoły wspólnie otrzymały nagrodę fair play przyznaną przez FIFA w lutym 1999 roku (Chehabi, 2001). Sytuacja taka zapewne przynajmniej częściowo wynikała $\mathrm{z}$ instrukcji, jakie zawodnicy mieli otrzymać od swoich państw. Jednak można tu dostrzec także wpływ nastawienia samych sportowców na pokojową symbolikę widowiska. Jak powiedział jeden $\mathrm{z}$ amerykańskich zawodników Eric Wynalda w kontekście meczu, był on „wspaniałą szansą aby piłka nożna zbliżyła dwa narody” oraz „pomiędzy dwoma krajami istniały oczywiste różnice polityczne, ale jako dyplomaci sportu możemy wyjść i pokazać, że są ważniejsze rzeczy, jak stosunki międzyludzkie" (Kianpour, 2014). Sytuacja ta była w pewnym sensie ponowieniem pozytywnego efektu kontaktu sportowego, do jakiego doszło wcześniej w zapasach. Dzięki pożądanemu zachowaniu sportowców udało się bowiem wzbudzić pozytywne nastawienie pomiędzy dwoma tradycyjnie wrogimi narodami.

Mimo że można było dostrzec wyraźną chęć ze strony obu państw, aby wykorzystać fakt odbywania się pomiędzy nimi meczu mistrzostw świata w piłce nożnej do zbliżenia, pojawiały się także bardzo liczne trudności związane z jego przebiegiem, szczególnie ze strony irańskiej. Problemy pojawiały się na każdym kroku, poczynając od faktu, iż Iran został określony jako „Zespół B”, podczas gdy Stany Zjednoczone jako „Zespół A”. Zgodnie z regulaminem FIFA podczas przedmeczowego uściśnięcia dłoni zespół B podchodzi do zespołu A. Tymczasem irański Najwyższy Przywódca Ali Chamenei zakazał drużynie podchodzenia do Amerykanów. Po negocjacjach prowadzonych przez obsługującego mecz $\mathrm{z}$ ramienia FIFA, urodzonego w Iranie, Mehrdada Masoudiego udało się ustalić, że to Amerykanie podejdą do Irańczyków. Pojawił się także problem z antyirańską organizacją finansowaną przez reżim Saddama Husseina - Mujahedin Khalq. Kupiła ona 7000 biletów na odbywający się w Lyonie mecz i planowała zorganizować protest. W związku $\mathrm{z}$ tym organizatorzy poinstruowali realizatorów transmisji, aby nie pokazywali wybranych części trybun (Billingham, 2014). Co ciekawe, w nawiązaniu do meczu Stany Zjednoczone zobowiązały się względem Iranu, że wprowadzą prawo zakazujące kontaktów z tą organizacją (Marlowe, 1998). 
Jeżeli chodzi o przebieg meczu, był on korzystny dla Iranu. Irańczycy wyszli na prowadzenie 2-0 po golach strzelonych przez Hamida Estiliego i Mehdiego Mahdavikii. Amerykanom udało się, co prawda, strzelić gola kontaktowego (strzelcem był Brian McBride), jednak to Iran odniósł pierwsze w historii tego kraju zwycięstwo w finałach Mistrzostw Świata w piłce nożnej. Wygrana z USA została w Iranie odebrana z wielką radością, podobnie jak wcześniej awans do finału Mistrzostw Świata po pokonaniu Australii (Billingham, 2014). Irańczycy, poza pewnymi wyjątkami, nie eksponowali jednak wyższości nad Amerykanami, a raczej „nowy wizerunek” i „powrót do normalności” (Amado, Amato, 2001, s. 108).

Po meczu, który wzbudził w USA spore zainteresowanie, mimo że w normalnych okolicznościach piłka nożna jest w tym kraju sportem o stosunkowo małej popularności (Kianpour, 2014), pojawiły się opinie, iż uczynił on więcej dla naprawy relacji dwustronnych niż dekady dyplomacji (Billingham, 2014) oraz że miał wielki potencjał, jeśli chodzi o procesy tranzycyjne w kontekście stosunków amerykańsko-irańskich (Amado, Amato, 2001). Szczególną uwagę zwracano na jego funkcję humanizowania drugiego kraju. Jeden $\mathrm{z}$ obserwatorów miał stwierdzić, że dzięki meczowi „Amerykanie byli w stanie dostrzec w Irańczykach fanów sportu i ludzi, zamiast terrorystów" (Kessler, 2009, s. 42). W opiniach tych można dostrzec typowy dla dyplomacji publicznej i zarazem dyplomacji sportowej wpływ poszczególnych wydarzeń czy działań przede wszystkim na społeczeństwa. W kontekście wykorzystywania sportu do aranżowania zbliżenia pomiędzy wrogimi sobie państwami, element humanizowania wydaje się właśnie szczególnie istotny, bowiem często dochodzi do sytuacji, że na skutek działalności informacyjnej rządu społeczeństwo wrogiego kraju jest w takim państwie przez wiele lat dehumanizowane.

\section{WYMIANY SPORTOWE PO 1998 ROKU}

Opisany wyżej mecz piłkarski można traktować jako swego rodzaju moment przełomowy, jeżeli chodzi o amerykańsko-irańską dyplomację sportową, podobnie jak wcześniejszą wizytę amerykańskich zapaśników w Iranie. Obydwa wydarzenia w pewnym sensie stworzyły podwaliny pod kolejne wymiany sportowe. Zatem już 18 miesięcy po meczu mistrzostw świata, w 2000 roku, zorganizowano w Pasadenie w USA towarzyskie spotkanie pomiędzy reprezentacjami USA i Iranu w piłce nożnej. Jak stwierdził wspominany wcześniej 
Masoudi z FIFA, mecz ten był jeszcze istotniejszy, ponieważ jego organizacja wymagała współpracy obu stron, a także że mogło do niego dojść wyłącznie dzięki sukcesowi spotkania we Francji (Billingham, 2014). Trudno nie zgodzić się szczególnie z tym pierwszym stwierdzeniem. Do meczu USA-Iran w ramach Mistrzostw Świata prawdopodobnie doszłoby nawet, gdyby nie przeprowadzono poprzedzających go negocjacji dotyczących kwestii spornych oraz gdyby dwa państwa chciały go wykorzystać nie do nawiązania współpracy, ale do udowodnienia wzajemnej wyższości. Organizacja meczu na terenie jednego z państw wymagała już jednak obustronnej woli, w tym politycznej.

Lokalizacja meczu w sąsiedztwie Los Angeles była nieprzypadkowa, bowiem w mieście tym mieszka największa populacja Irańczyków poza Iranem. Przed spotkaniem doszło oczywiście do szeregu ustaleń dotyczących kwestii bezpieczeństwa czy przekraczania granicy, w których uczestniczyli przedstawiciele obu narodowych federacji piłkarskich (Asgharirad, 2012). Wymiany sportowe wymagają bowiem licznych ustaleń, co jest jednak utrudnione w przypadku braku stosunków dyplomatycznych. Swoistym wybiegiem w takich sytuacjach jest prowadzenie negocjacji za pośrednictwem federacji sportowych, jak miało to miejsce $w$ tym przypadku, czy organizacji pozarządowych, jak w przypadku wcześniejszych wymian w zapasach.

Mecz w Pasadenie zakończył się remisem 1: 1 (The Oman Observer, 2013). Obok spotkania na poziomie reprezentacyjnym drużyna Iranu rozegrała także serię meczów z drużynami klubowymi (Khanlari, 2014), zatem wymianę tę powinno się raczej rozpatrywać jako serię spotkań, aczkolwiek największe znaczenie miał oczywiście mecz na poziomie reprezentacji. Był on odbierany jako sukces w kontekście dyplomatycznym, jednak okazał się niemal niedostrzeżony przez społeczeństwa obu państw - przykładowo nie był transmitowany w Iranie, w obawie przed antyrządowymi manifestacjami w jego trakcie. Ponadto twierdzi się, że ewentualne korzyści w kontekście dyplomacji publicznej z meczu zostały zaprzepaszczone w związku z wydarzeniami z 11 września 2001 roku, co można dostrzec chociażby w fakcie, iż nie doszło do planowanego wcześniej meczu rewanżowego (Asgharirad, 2012).

Okres pierwszej dekady XXI wieku charakteryzował się zahamowaniem procesu zbliżenia pomiędzy Iranem a Stanami Zjednoczonymi. Było to widoczne także w kontekście wymian sportowych, aczkolwiek nie zostały one zakończone. Administracja George’a W. Busha kontynuowała chociażby rozpoczętą przez Clintona serię wymian zapaśniczych - 5 z 7 wizyt drużyny amerykańskiej 
w Iranie było sponsorowane przez rząd (Asgharirad, 2012), ogólnie jednak był dostrzegalny silny regres wymian sportowych. Jeżeli chodzi o piłkę nożną, w 2004 roku amerykańska drużyna Los Angeles Galaxy zaprosiła reprezentację Iranu, aby zagrać wspólnie mecz towarzyski. Ustalenia były już bardzo zaawansowane, jednak doszło do impasu w negocjacjach w kontekście pobierania od zawodników na granicy odcisków palców, wskutek czego do meczu nie doszło. W późniejszym okresie pojawiły się jeszcze inicjatywy odnośnie do organizacji meczów towarzyskich pomiędzy piłkarskimi drużynami klubowymi z obu krajów, okazały się jednak nieskuteczne. Nieudane próby zorganizowania wymian sportowych dotyczyły też innych dyscyplin, takich jak kajakarstwo (Asgharirad, 2012). Udało się natomiast zorganizować kontakty w tenisie stołowym i koszykówce - przykładowo w lipcu 2008 roku reprezentacja Iranu w koszykówce odbyła treningi z zawodnikami ligi NBA w Salt Lake City (Baktiari, 2014). Generalnie wymiany sportowe stały się najbardziej popularną formą dyplomacji kulturalnej Stanów Zjednoczonych względem Iranu, aczkolwiek nie jedyną. Do innych należały chociażby wymiany studenckie - amerykańskie uczelnie starały się pozyskiwać studentów irańskich (Asgharirad, 2012; Rahman, Parvez, 2011), czy artystyczne - jak zaproszenie do USA irańskich muzyków w 2009 roku, aby uczyli się o amerykańskiej muzyce ludowej (Broder, 2015).

Mimo że różne formy dyplomacji sportowej pomiędzy USA a Iranem były kontynuowane, szanse na zbliżenie dwóch państw zmalały po wyborze na prezydenta Iranu bardziej konserwatywnego Mahmuda Ahmadineżada w 2005 roku. Wcześniej jeszcze doszło do zwiększenia napięcia po tym, jak prezydent George W. Bush zaliczył Iran obok Iraku i Korei Północnej do „Osi Zła” - w 2002 roku, gdy okazało się, że Iran rozwija instalacje nuklearne w miejscowościach Natanz i Arak (US-Iran relations: A brief guide, 2014). Bush określił także Iran jako zagrożenie dla światowego pokoju (Countrywatch, 2015). Sytuacja pozostawała stosunkowo niezmienna także po objęciu prezydentury w Stanach Zjednoczonych przez Baracka Obamę. Dalej dochodziło bowiem do pewnych wymian sportowych, jednak pojawiały się także problemy przy ich organizacji. Przykładowo, amerykańskim zawodniczkom badmintona podróżującym do Iranu na zawody w 2009 roku odmówiono przyznania wiz (Asgharirad, 2012). 


\section{INTENSYFIKACJA KONTAKTÓW SPORTOWYCH OD 2013 ROKU}

Pewną intensyfikację wymian sportowych (i generalnie dyplomacji publicznej na linii USA-Iran) można było dostrzec po objęciu prezydentury w Iranie przez Hasana Rouhaniego w 2013 roku. W tym samym roku Iran, Rosja i Stany Zjednoczone wzięły udział w historycznym wydarzeniu zapaśniczym w nowojorskiej Grand Central Station. W marcu 2014 roku Iran wziął udział w Pucharze Świata w Los Angeles, natomiast w czerwcu 2014 roku w turnieju w zapasach w stylu greko-romańskim Curby Cup. Z kolei w sierpniu 2014 roku, na zaproszenie amerykańskiej federacji siatkarskiej USA Volleyball, reprezentacja Iranu rozegrała w USA cztery mecze towarzyskie: w Los Angeles, Anaheim, San Diego i Irvine. Organizacja meczów w aż czterech miejscach wymagała koordynacji i negocjacji $\mathrm{z}$ wieloma stronami. $\mathrm{W}$ ten sposób miano przełamać szereg barier pomiędzy Iranem a Stanami Zjednoczonymi (Baktiari, 2014; Slavin, 2015). Dochodziło także do wymian w podnoszeniu ciężarów czy piłce wodnej (Wiseman, 2015). Mimo że nie wszystkie inicjatywy dochodziły do skutku, dostrzec można było dużą intensyfikację kontaktów sportowych pomiędzy krajami.

Ponowne wzmożenie kontaktów dyplomacji sportowej od 2013 roku szło niejako w parze z politycznym otwarciem Iranu. Na miesiąc po objęciu prezydentury, we wrześniu 2013 roku, Hassan Rouhani wziął udział w obradach ONZ w Nowym Jorku. Wizyta w USA została zwieńczona rozmową telefoniczną z prezydentem Barackiem Obamą, co oceniano jako „potencjalny początek nowych stosunków pomiędzy Iranem a Stanami Zjednoczonymi” (Maloney, 2013). Polityk swoją wizytą zrobił bardzo pozytywne wrażenia na Amerykanach. Wcześniej jeszcze Rouhani miał powiedzieć, iż podczas swojej wizyty w Nowym Jorku planuje wznowić rozmowy dotyczące irańskiego programu nuklearnego (Foroohar, Salehi, 2013).

Wydaje się, że bardzo istotny wpływ na rozwój dyplomacji sportowej i generalnie kontaktów pomiędzy Stanami Zjednoczonymi a Iranem ma osoba sprawująca aktualnie władzę w Iranie, w większym stopniu niż ma to miejsce w przypadku prezydentów Stanów Zjednoczonych. Wymiany sportowe rozpoczęły się za rzadów Chatamiego, potem zaś doszło do ich ograniczenia, kiedy władzę objął Ahemdineżad. Po wygraniu wyborów przez Rouhaniego znów można było zaobserwować intensyfikację kontaktów sportowych ze Stanami Zjednoczonymi.

Największym punktem spornym w stosunkach pomiędzy Iranem a USA pozostawał irański program atomowy. Na skutek pewnej zmiany w podejściu 
decydentów irańskich za prezydentury Rouhaniego rozpoczęto długotrwałe i trudne negocjacje, które zwieńczono porozumieniem, zgodnie z którym Iran nie będzie miał możliwości stworzenia broni atomowej, kontynuując jednocześnie swój program dotyczący cywilnego wykorzystania energii atomowej. Układ został podpisany w Wiedniu 14 lipca 2015 roku przez przedstawicieli Iranu oraz Chin, Francji, Niemiec, Rosji, Wielkiej Brytanii i Stanów Zjednoczonych (Joint Comprehensive Plan of Action, 2015). Na skutek porozumienia Rada Bezpieczeństwa Organizacji Narodów Zjednoczonych wydała rezolucję tworzącą podstawy do zniesienia nałożonych na Iran sankcji ekonomicznych. Rezolucja ta była wynegocjowana wraz ze wspomnianym wcześniej układem określanym jako Iran Nuclear Deal (Sengupta, 2015).

\section{PODSUMOWANIE}

Porozumienie w sprawie irańskiego programu atomowego z 2015 roku stanowi wielki przełom, jeżeli chodzi o stosunki amerykańsko-irańskie, aczkolwiek państwa w dalszym ciągu nie utrzymują stosunków dyplomatycznych. Pojawia się w związku z tym pytanie dotyczące wpływu dyplomacji sportowej na rozwój stosunków pomiędzy Iranem a Stanami Zjednoczonymi oraz na ewentualne możliwości dalszego zbliżenia? Wydaje się, że próba odpowiedzi wiąże się z koniecznością dostrzeżenia licznych trudności związanych z nawiązywaniem kontaktów i wzajemnym otwieraniem się państw, które tradycyjnie określały się wzajemnie jako wrogów. Nieufności polityków towarzyszy w takiej sytuacji niechęć do zmiany dominującej linii politycznej ze strony społeczeństw, w których drugi kraj nierzadko podlegał wieloletniemu „demonizowaniu”. Zwykłe nawiązanie kontaktu może $\mathrm{w}$ takiej sytuacji wiązać się z oporem społecznym i obawą przywódców politycznych przed krytyką i ewentualną utratą twarzy $\mathrm{w}$ przypadku fiaska inicjatywy. $Z$ pozoru apolityczny sport daje $\mathrm{w}$ takich sytuacjach politykom swoisty bufor bezpieczeństwa, $\mathrm{w}$ związku z pozorną apolitycznością, a także zapewnia możliwość wysondowania obywateli i przygotowania ich na zmianę linii politycznej.

Intensywność wymian sportowych pomiędzy Iranem i Stanami Zjednoczonymi była silnie skorelowana z osobami sprawującymi władzę w poszczególnych państwach, w szczególności w Iranie. Do intensyfikacji dochodziło w okresach rządów bardziej liberalnych Chatamiego i Rouhaniego, natomiast podczas prezydentury Ahemdineżada doszło do wyraźnego regresu, jeśli chodzi o dyplomację 
sportową. Chociaż w mniejszym stopniu, to podobną zależność można także zaobserwować po stronie amerykańskiej, bowiem dyplomacja sportowa pomiędzy krajami „rozkwitała” za rządów uznawanych za bardziej liberalnych Clintona i Obamy. Obserwacja ta nasuwa wniosek, że dyplomacja sportowa pomiędzy Iranem i Stanami Zjednoczonymi możliwa była tylko w sytuacji politycznej woli zbliżenia, co potwierdza hipotezę odnośnie do jej wtórnego charakteru jeśli chodzi o kształtowanie stosunków dwustronnych. Trzeba jednak stwierdzić, iż dzięki oddolnemu charakterowi dyplomacja sportowa należy do wyjątkowych narzędzi jeżeli chodzi o możliwość wpływania na postawę z pozoru wrogich sobie społeczeństw, co wiąże się zapewne $\mathrm{z}$ istotą samego sportu.

Warto podjąć rozważania nad doborem dyscyplin sportowych, których dotyczyła amerykańsko-irańskia dyplomacja sportowa. Chociaż toczyła się ona $\mathrm{z}$ wykorzystaniem szeregu sportów, to szczególną rolę odgrywały wymiany w zapasach i piłce nożnej. Według Houchanga Chechabiego (2001) były to idealnie dobrane sporty, ponieważ w zapasach w stylu wolnym oba narody należały do najlepszych na świecie, podczas gdy w piłce nożnej oba były stosunkowo słabe. Sytuacja taka gwarantowała, iż nie dojdzie do upokarzającej porażki żadnej ze stron. Mimo że w Iranie tradycyjnie popularne były zapasy i ten sport był preferowany przez Islamską Radę Rewolucyjną, w sposób niekontrolowany popularność zyskiwała też piłka nożna, szczególnie od lat 90. XX wieku. Tymczasem w Stanach Zjednoczonych piłka nożna tradycyjnie traktowana jest jako sport nieco niszowy w porównaniu z najbardziej popularnymi w tym kraju grami zespołowymi: futbolem amerykańskim, baseballem, koszykówką czy hokejem na lodzie. Fakt ten sprawił, iż o ile mecz mistrzostw świata wzbudził jeszcze spore zainteresowanie wśród Amerykanów, to już organizowane później towarzyskie kontakty w piłce nożnej nie. W związku z tym trzeba stwierdzić, iż dobór dyscyplin sportowych będących medium dyplomacji sportowej pomiędzy USA a Iranem był tylko częściowo adekwatny, aczkolwiek jako jego mocną stronę należy uznać stosunkowo niewielkie ryzyko pobudzania nacjonalistycznych emocji, do czego mogłoby dojść w przypadku kontaktu w sporcie, który byłby uznawany za prestiżowy w obu państwach. Warto w tym miejscu zwrócić także uwagę na pewną specyfikę dyplomacji sportowej Iran-Stany Zjednoczone, w której istotniejsze zdawały się „swoiste” otoczki kontaktów sportowych, obejmujące dobre traktowanie zawodników czy wymiany uprzejmości, niż wynik sportowy. 
Bibliografia:

Amado, G., Amato, R. (2001). Some distinctive characteristics of transitional change. W: G. Amado, A. Amrose (red.), The Transitional Approach to Change (s. 87-118). London: Karnac Books Ltd.

Asgharirad, J. (2012). U.S. Diplomacy Towards Iran during the George W. Bush Era. Berlin: Freie Universität Berlin.

Baktiari, B. (2014). Sports Diplomacy With Iran: Breaking Barriers, Bridging Differences. Pobrane z: http://www.huffingtonpost.com/bahman-baktiari/sports-diplomacy-with-iran_b_5772374.html.

Billingham, N. (2014). 98: The Most Politically Charged Game in World Cup History. Pobrane z: http://www.fourfourtwo.com/features/98-most-politically-chargedgame-world-cup-history\#X4Hgu7CXPiXYus4j.99.

Broder, J. (2015). Banjo Diplomacy. Newsweek Global, vol. 165, Issue 4, s. 16-19.

Chehabi, H.E. (2001). Sports Diplomacy between the United States and Iran. Diplomacy and Statecraft, vol. 12, nr 1, s. 89-90.

Chehabi, H.E. (2006). The Politics of Football in Iran. Soccer and Society, vol. 7, nr. 2-3, s. $233-261$.

Countrywatch (2015). 2015 Country Review: United States. Houston: CountryWatch Inc. Foroohar, K., Salehi, Y. (2013). Rohani Says Iran Plans to Restart Nuclear Talks in N.Y.. Pobrane z: http://www.bloomberg.com/news/articles/2013-09-10/rohani-saysiran-plans-to-restart-nuclear-talks-in-new-york.

Hauss, C. (2015). Comparative Politics. Domestic Responses to Global Challenges. Stanford: Wadsworth Publishing.

Joint Comprehensive Plan of Action (2015). Pobrane z: http://apps.washingtonpost. $\mathrm{com} / \mathrm{g} /$ documents/world/full-text-of-the-iran-nuclear-deal/1651/.

Kaussler, B., Newkirk, A.B. (2012). Diplomacy in Bad Faith: American-Iranian Relations Today. Diplomacy \& Statecraft, vol. 23, s. 347-380. DOI: 10.1080 /09592296.2012.679493.

Kessler, D. (2009). The Citizens' Affair: Sports and Tourism in Post-1998 United States-Iran Relations. Stanford Journal of International Relations, vol. XI, nr 1, s. 38-49.

Khanlari, S. (2014). Sport, in the Name of Iranian-US Diplomacy. Pobrane z: http://www. yourmiddleeast.com/culture/sport-in-the-name-of-iranianus-diplomacy_24809.

Kianpour, S. (2014). John Kerry, Iran and Football Diplomacy. Pobrane z: http://www. bbc.com/news/blogs-echochambers-28114865.

Kriesberg, L. (2015). Realizing Peace. A Constructive Conflict Approach. Oxford: Oxford University Press.

Maloney, S. (2013). The Rouhani Tsunami: A Presidential Phone Call Offers Another Iranian Surprise. Pobrane z: http://www.brookings.edu/blogs/markaz/posts/2013/09/27-iran-us-make-history-rouhani-unga.

Marlowe, L. (1998). Iran and US Use Football to Score Diplomatic Goals. Pobrane z: http://www.irishtimes.com/news/iran-and-us-use-football-to-score-diplomaticgoals-1.165937. 
Milinski, M. (2010). Case Study: Iran and the United States. Pobrane z: http://www. culturaldiplomacy.org/pdf/case-studies/cs-martinmilinski.pdf.

Miller, T., Lawrence, G., McKay, J., Rowe, D. (2001). Globalization and Sport. Playing the World. London: Sage.

Ministerstwo Spraw Zagranicznych RP. (2014). Nowe Wymiary Dyplomacji: Dyplomacja Publiczna Raport 2013-2014. Pobrane z: https://www.msz.gov.pl/resource/ b3385a49-de88-4f59-84ed-76b9ee1296ca:JCR.

Polski Komitet Olimpijski. (2014). O sporcie i dyplomacji. Pobrane z: http://www.olimpijski.pl/pl/aktualnosci,89/909,o-sporcie-i-dyplomacjio-sporcie-i-dyplomacji.html. Public Papers of the Presidents of the United States. Administration of William J. Clinton. (1998). Pobrane z: https://www.gpo.gov/fdsys/pkg/PPP-1998-book1/pdf/PPP-1998-book1-doc-pg1098.pdf.

Rahman, M.S., Parvez, S. (2011). Taming the Persians: US Public Diplomacy and Iran. Jindal Journal of International Affairs. vol. 1, issue 1, s. 31-47.

Sengupta, S. (2015). U.N. Moves to Lift Iran Sanctions After Nuclear Deal, Setting Up a Clash in Congress. Pobrane z: http://www.nytimes.com/2015/07/21/world/middleeast/security-council-following-iran-nuclear-pact-votes-to-lift-sanctions.html.

Slavin, B. (2015). Wrestling's Curby Cup Next Move in US-Iran Sports Diplomacy. Pobrane z: http://www.al-monitor.com/pulse/originals/2015/06/iran-us-sports-diplomacy-wrestling-curby-cup.html\#ixzz3jA7qDPuD.

The Oman Observer (2013). Iran Mulls Football Diplomacy. Pobrane z: http://omanobserver.om/iran-mulls-football-diplomacy/.

US-Iran relations: A brief guide (2014). Pobrane z: http://www.bbc.com/news/world-middle-east-24316661.

Wiseman, G. (2015). Isolate or Engage. Adversarial States, US Foreign Policy, and Public Diplomacy. Stanford: Stanford University Press. 